\title{
PENGARUH PENDEKATAN MATEMATIKA REALISTIK TERHADAP KEMAMPUAN BERPIKIR KREATIF DAN KONEKSI MATEMATIS SISWA
}

\author{
Durachman \\ Sekolah Dasar Negeri Cilembu \\ E-Mail:durachmanspd@gmail.com \\ Edo Dwi Cahyo \\ Institut Agama Islam Negeri Metro \\ E-Mail:edodwicahyo@gmail.com
}

Tapis : Jurnal Penelitian Ilmiah
Website: $\frac{\text { http:/ / e-journal.metrouniv.ac.id/index.php/tapis/index }}{\text { DOI: } \underline{\text { http://doi.org/10.32332/tapis.v4i1.1954 }}}$
This article is distributed under the terms of
the Creative Commons Attribution-NonCommercial 4.0 International License

\begin{abstract}
Mathematics is often regarded as a boring subject, meaningless and less related to daily life. The teacher can use a variety of learning approaches that are interesting and make students more focused on paying attention and understanding the subject matter. The realistic mathematics approach in this study is used as a way to improve students' abilities especially in mathematics. The research method used is quasi-experimental with a nonequivalent control group. The population in this study were Madrasah Ibtidaiyah Negeri students in Bandung and Madrasa Ibtidaiyah Negeri Sumedang City. The results showed that the ability to think creatively and mathematical connections of students in the experimental class were better than students who obtained conventional mathematics learning. In addition, students' responses to mathematics learning using a realistic mathematical approach were interpreted as good, this is based on the results of a questionnaire that $86.08 \%$ of students were in the experimental class.
\end{abstract}

Keyword: Realistic Mathematic Approach, Mathematical Creative Thinking Ability, Mathematical Connection Ability

\begin{abstract}
Abstrak
Matematika sering dianggap sebagai mata pelajaran yang membosankan, tidak bermakna serta kurang terkait dengan kehidupan sehari-hari. Guru dapat menggunakan berbagai pendekatan pembelajaran yang menarik dan membuat siswa lebih fokus dalam memperhatikan dan memahami materi pelajaran. Pendekatan matematika realistik didalam penelitian ini digunakan sebagai salah satu cara untuk meningkatkan kemampuan siswa khususnya pada mata pelajaran matematika. Metode penelitian yang digunakan yaitu kuasi eksperimen dengan kelompok kontrol tidak ekuivalen. Populasi dalam penelitian ini adalah siswa Madrasah
\end{abstract}


Ibtidaiyah Negeri yang berada di kota Bandung dan Madrasah Ibtidaiyah Negeri kota Sumedang. Hasil penelitian menunjukkan bahwa kemampuan berpikir kreatif dan koneksi matematis siswa pada kelas eksperimen lebih baik dibandingkan siswa yang memperoleh pembelajaran matematika secara konvensional. Selain itu respon siswa terhadap pembelajaran matematika dengan menggunakan pendekatan matematika realistik di interpretasikan baik, hal ini berdasarkan hasil angket bahwa 86,08\% siswa kelas eksperimen.

Kata Kunci: Pendekatan Matematika Realistik, Kemampuan Berpikir Kreatif Matematis, Kemampuan Koneksi Matematis

\section{A. PENDAHULUAN}

Salah satu disiplin ilmu yang mempunyai peranan penting dalam kehidupan adalah matematika, dalam belajar matematika siswa diharapkan dapat melatih cara berpikir logis dan mengembangkan kreativitas, serta meningkatkan kesadaran pengembangan budaya dengan mengenal berbagai pola hubungan, pengalaman dalam menyelesaikan masalah yang dihadapi dalam kehidupan. ${ }^{1}$ Karakteristik matematika bersifat abstrak, sifat ini menyebabkan banyak siswa mengalami berbagai kesulitan dalam mempelajari matematika terutama dalam memahami konsep-konsep dan menyelesaikan masalah matematis serta mengalami kesulitan dalam mengaplikasikan matematika dalam kehidupan seharihari. $^{2}$

Matematika merupakan ilmu tentang logika mengenai besaran bentuk, susunan, dan konsep-konsep yang berhubungan satu dengan yang lainnya. Selama ini kita mungkin menerima begitu saja pengajaran matematika di sekolah tanpa mempertanyakan mengapa atau untuk apa matematika harus diajarkan. Tidak jarang muncul keluhan bahwa matematika adalah mata pelajaran yang membuat pusing peserta didik bahkan dianggap sebagai pelajaran yang sulit dipahami oleh sebagian siswa. ${ }^{3}$

Proses pembelajaran pada hakekatnya untuk mengembangkan aktivitas dan kreatifitas peserta didik melalui berbagai interaksi dan pengalaman belajar. Kreativitas juga tidak hanya ditemukan dalam bidang tertentu melainkan juga merupakan bagian dari kehidupan sehari-hari. Kegunaan matematika terlihat dari peran pentingnya dalam perkembangan ilmu pengetahuan dan teknologi. Arus perkembangan zaman yang selalu berubah menuntut setiap orang memiliki pola pikir 2009).

${ }^{1}$ E. Swangsih and Tiurlina, Model Pembelajaran Matematika (Bandung: UPI PRESS,

2 D. Tarigan, Pembelajaran Matematika Realistik (Jakarta: Depdiknas, 2006).

${ }^{3}$ E. Suherman, Evaluasi Pembelajaran Matematika (Bandung: FPMIPA UPI, 2003). 
yang kritis, sistematis, kreatif, dan logis. Sikap dan cara berpikir ini dapat dikembangkan dengan mempelajari matematika. Proses pembelajaran yang inovatif dan lingkungan belajar yang baik akan berdampak terhadap keberhasilan proses pembelajaran matematika.

Pada skala yang lebih kecil, Khususwanto melakukan penelitian yang menghasilkan kesimpulan bahwa indikasi lemahnya kemampuan berpikir kreatif siswa merupakan akibat dari faktor proses pembelajaran yang dilakukan ternyata didominasi oleh pembelajaran yang bersifat tradisional, dan prosedural. ${ }^{4}$

Tujuan pembelajaran matematika pada salah satu kompetensi dasar di antaranya menunjukkan sikap logis, kritis, analitis, konsisten dan teliti, bertanggung jawab, responsif, dan tidak mudah menyerah dalam memecahkan masalah. Hal ini menguatkan penyataan bahwa kurikulum yang dikembangkan sangat diperlukan sebagai instrumen untuk mengarahkan peserta didik menjadi manusia berkualitas yang mampu dan proaktif menjawab tantangan zaman yang selalu berubah, manusia terdidik yang beriman dan bertakwa kepada Tuhan yang Maha Esa, berakhlak mulia, sehat, berilmu, cakap, kreatif, mandiri, warga negara yang demokratis dan bertanggung jawab. ${ }^{5}$ Tercapainya tujuan pendidikan tersebut dapat dipengaruhi oleh faktor intern dan faktor ekstern. ${ }^{6}$ Faktor intern terdiri dari faktor jasmani, psikologi dan kelelahan.

Hiebert berpandangan bahwa "studens who reflect on what they do and communicate with others about it are in the best position to build useful connections in Mathematics". Siswa yang melakukan refleksi terhadap yang mereka kerjakan dan mengkomunikasikannya kepada yang lain dapat membangun kemampuan koneksi matematis yang berguna. Kegiatan refleksi ini diantaranya memeriksa hasil dari masalah yang diberikan, menelusuri proses berpikir mereka sendiri, meninjau strategi yang digunakan, serta menentukan strategi yang dapat dan tidak dapat digunakan. $^{7}$

Berkaitan dengan kemampuan koneksi matematis, Wahyudin menerangkan bahwa kemampuan koneksi bukan hanya kemampuan yang diajarkan dan digunakan dalam matematika, tetapi lebih dari itu

\footnotetext{
${ }^{4}$ Khususwanto, “Pembelajaran Matematika Dengan Pendekatan Resourcebased Learning Untuk Meningkatkan Kemampuan Berpikir Kreatif Matematis SMP" (Universitas Pendidikan Indonesia, 2013).

${ }^{5}$ Kementrian Pendidikan dan Kebudayaan, "Permendikbud No.64 Tentang Standar Isi Pendidikan Dasar Dan Menengah" (2013).

6 Pitajeng, Pembelajaran Matematika Yang Menyenangkan (Jakarta: Depdiknas, 2006).

${ }^{7}$ D. Jarret, “Open-Ended Problem Solving Weaving a Web of Idea Northwest Teacher," Potland: Northwest Regional Educational Laboratory 1, no. 1 (2000).
} 
kemampuan koneksi merupakan keterampilan dalam menghadapi masalah dalam kehidupan sehari-hari. ${ }^{8}$ Hal ini menunjukkan bahwa matematika banyak digunakan dalam bidang ilmu terkait diantaranya seperti bidang perdagangan, bisnis dan sebagainya.

Selain kemampuan koneksi matematis, kemampuan berpikir kreatif menjadi fokus lain dalam pembelajaran matematika. Seperti yang dijelaskan Ruseffendi bahwa sifat kreatif akan tumbuh dalam diri anak jika adanya latihan, dan pembiasaan sejak dini dengan melakukan eksplorasi, inquiry, penemuan dan pemecahan masalah. Siswa dibiasakan bertanya atau diberi pertanyaan "mengapa" sebagai sarana efektif untuk menuju kemampuan berpikir kreatif. Selama ini guru hanya mengutamakan logika dan kemampuan komputasi (hitung-menghitung) sehingga kreativitas dianggap bukanlah sesuatu hal yang penting dalam proses belajar mengajar di dalam kelas. ${ }^{9}$

Ada berbagai macam aspek dari dalam diri siswa yang perlu dipahami, di antaranya aspek perkembangan intelektual siswa dalam belajar, dan sifat-sifat siswa sesuai kelompok umurnya, serta perbedaan individual siswa. ${ }^{10}$ Ketiga aspek tersebut merupakan inti dari usaha pemahaman guru terhadap siswa yang dapat terlaksana dengan memilih pendekatan pembelajaran yang tepat.

Salah satu pendekatan pembelajaran matematika yang dapat diterapkan untuk mengembangkan kemampuan matematis khususnya kemampuan berpikir kreatif dan koneksi matematis siswa adalah menggunakan pendekatan pembelajaran PMR (Pendekatan Matematika Realistik). Dalam PMR, pembelajaran matematika lebih memusatkan kegiatan belajar pada siswa dan lingkungan serta bahan ajar yang disusun sedemikian sehingga siswa lebih aktif mengkonstruksi atau membangun sendiri pengetahuan yang akan diperolehnya.

Menurut Freudenthal "Pemahaman yang kuat merupakan daya dukung dalam proses belajar siswa, berarti proses pembelajaran matematika yang dilaksanakan harus lebih mengaplikasikan pengalamanpengalaman siswa dalam kehidupannya sehingga dapat dihubungkan dengan pengembangan materi pembelajaran matematika yang disesuaikan dengan tingkatan kognitif siswa, diharapkan siswa termotivasi untuk terlibat aktif dan kreatif dalam kegiatan pembelajaran".11 Adapun subjek

8 Wahyudin, "Pembelajaran Dan Model Model Pembelajaran: Pelengkap Untuk Meningkatkan Pedagogis Para Guru Dan Calon Guru Profesional” (Bandung, 2008).

${ }^{9}$ E. T. Ruseffendi, Pendidikan Matematika III (Jakarta: Depdikbud Proyek Pembinaan Tenaga Kependidikan Perguruan Tinggi, 1998).

${ }^{10}$ M Asrori, Psikologi Pembelajaran (Bandung: CV Wacana Prima Press, 2009).

11 A. Wijaya, Pendidikan Matematika Realistik (Yogyakarta: Graha Ilmu, 2011). 
penelitian menggunakan populasi yang memiliki karakteristik atau sifat yang sama, sekolah berstatus negeri yang terakreditasi B dengan jumlah siswa, tenaga pendidik yang mempunyai latar belakang pendidikan yang sama, didukung dengan sarana dan prasarana pendidikan yang memenuhi kriteria untuk memdapatkan bantuan dan pelayanan dari Kementrian Agama Negera Indonesia. Selanjutnya penelitian disesuaikan dengan kurikulum satuan pendidikan pada materi penjumlahan dan pengurangan pecahan agar penelitian tidak menggangu secara signifikan kegiatan belajar siswa disekolah Madrasah Ibtidaiyah Negeri.

Atas berbagai pertimbangan di atas, dilakukan penelitian dengan judul “Pengaruh Pendekatan Matematika Realistik terhadap Kemampuan Berpikir Kreatif dan Koneksi Matematis Siswa Kelas V Madrasah Ibtidaiyah Negeri". Adapun materi penelitian yang dilaksanakan, adalah penjumlahan dan pengurangan pecahan biasa.

\section{B. KAJIAN TEORI}

\section{Sejarah Matematika Realistik}

Treffers mengemukakan PMR (Pendekatan Matematika Realistik) pertama kali dikembangkan di Belanda pada tahun 1970, dalam waktu yang tak kurang dari 30 tahun dalam pengembangannya sebanyak 75\% sekolah-sekolah di Belanda telah menggunakan pendekatan matematika realistik. ${ }^{12}$ Sedangkan pada tahun 1990-an beberapa sekolah di Amerika Serikat mengadaptasi pendekatan matematika realistik sebagai pendekatan dalam pendidikan matematika dengan nama kurikulum Mathematics in Context. Adapun di negara Indonesia pembelajaran matematika realistik ini diperkenalkan pada tahun 2001 di beberapa perguruan tinggi secara collaborative melalui proyek pendidikan matematika realistik di tingkat sekolah dasar. ${ }^{13}$

Pendekatan matematika realistik menekankan pada pentingnya konteks nyata dan penggunaan situasi yang bisa dibayangkan oleh siswa, sebagai proses awal dalam mengkonstruksi pengetahuan matematika oleh siswa sendiri yang disebut reinvention terbimbing, dimana siswa diberikan kesempatan untuk mengalami proses yang mirip dengan penciptaan matematika yaitu, membangun sendiri alat dan gagasan matematika, menemukan sendiri hasilnya, serta memformalkan pemahaman dan strategi informalnya dengan bimbingan guru dan dukungan dari bahan pembelajaran.

\footnotetext{
12 Suherman, Evaluasi Pembelajaran Matematika.

13 Tarigan, Pembelajaran Matematika Realistik.
} 
Tarigan menjelaskan untuk melakukan mencipta ulang (to reinvent) matematika yang formal dan abstrak siswa diarahkan secara bertahap dari penggunaan pengetahuan sebelumnya dan penggunaan strategi dalam melakukan penyelesaian secara informal, intuitif, dan konkret menuju ke yang lebih formal, abstrak dan baku, dengan tujuan agar siswa mempunyai kemampuan dalam memperkaya pengalaman belajarnya (learning to do). Siswa mampu membangun pemahaman dan pengetahuan terhadap dunia sekitarnya (learning to know) Siswa dapat membangun pengetahuan dan kepercayaan dirinya (learning to be) Kesempatan untuk berinteraksi dengan individu atau kelompok yang bervariasi (learning to live together). ${ }^{14}$

Pembelajaran matematika harus lebih melibatkan siswa secara aktif dalam penemuan konsep sehingga siswa akan mengetahui bagaimana konsep-konsep itu dulu ditemukan. Hal ini sejalan dengan ungkapan Freudenthal yang mengkritik pengajaran matematika jika guru hanya mentransfer pengetahuan yang dimilikinya ke pikiran siswa, sebab bertentangan dengan cara matematikawan menemukan konsep matematika. ${ }^{15}$ Dalam pendekatan matematika realistik, makna matematika harus dilihat dalam berbagai aspek aplikasinya, antara lain dalam kegunaannya di dalam kehidupan sehari-hari, dalam pembelajaran lain dan dalam pemecahan masalah.

Swangsih \& Tiurlina menjelaskan pendekatan matematika realistik adalah suatu pendekatan yang menggunakan masalah realistik sebagai pangkal tolak pembelajaran, dan melalui matematisasi horizontal-vertikal siswa diharapkan dapat menemukan dan mengkonstruksi konsep-konsep matematika atau pengetahuan matematika formal. ${ }^{16}$ Adapun menurut Irzani "Pendekatan matematika realistik adalah pendekatan yang dikembangkan berdasarkan pemikiran Hans Freudenthal yang mengatakan bahwa matematika harus dikaitkan dengan reality dan matematika merupakan aktivitas manusia". ${ }^{17}$ Ini berarti pembelajaran matematika harus lebih dirasakan secara nyata oleh siswa dalam melakukan sebuah aktivitas dapat menemukan berbagai konsep serta gagasan dengan bimbingan orang dewasa dalam kehidupan sehari-hari.

\section{Tarigan.}

15 Lambertus, "Peningkatan Kemampuan Berpikir Kreatif Dan Kemampuan Pemecahan Masalah Matematik Siswa SD Melalui Pendekatan Matematika Realistik" (Universitas Pendidikan Indonesia, 2010).

16 Swangsih and Tiurlina, Model Pembelajaran Matematika.

17 Irzani, Pembelajaran Matematika Panduan Praktis Untuk Pengajar SD \& MI (Yogyakarta: Mandiri Graffindo Press, 2010). 


\section{Prinsip-prinsip Pendekatan Matematika Realistik}

Suherman \& dkk. (2003, hlm. 147) menjelaskan tiga prinsip utama dalam pendekatan matematika realistik, yaitu: Prinsip guided reinvention and didactical phenomenology, merupakan prinsip dimana siswa memperoleh kesempatan untuk menemukan konsep matematika berdasarkan kepada beberapa fenomena yang di dalamnya terdapat konsep matematika sesuai dengan kehidupan nyata yang dihadapinya. Selanjutnya prinsip progressive mathematization, artinya permasalahan yang nyata harus dijadikan titik awal pada pembelajaran matematika dalam mencapai matematika secara formal, dalam pembelajaran matematika yang nyata dapat dijadikan alat untuk membantu siswa mengerti dunianya.

Sementara itu, prinsip self developed models, pada prinsip ini pengetahuan matematika siswa dihubungkan dari pengetahuan matematika tidak formal ke pengetahuan matematika formal. model berfungsi sebagai alat mediator antara masalah pada alam nyata dengan dunia abstrak sebagai pengetahuan matematika.

Berdasarkan prinsip-prinsip pendekatan matematika realistik yang diuraikan jelas bahwa pada proses pembelajaran matematika menggunakan proses kedekatan dengan siswa dan harus relevan dengan kehidupan sehari-hari, siswa dapat menemukan kembali matematika secara berarti, maksudnya adalah siswa tidak menghafal suatu konsep yang mereka dapatkan dari gurunya, tetapi siswalah yang menemukan konsep matematika, penemuan konsep tersebut didapatkan dari pengalaman dan pengetahuannya, yang didukung oleh proses interaksi yang menjadi bagian hal yang penting untuk belajar matematika, sebuah interaksi perlu untuk membentuk pengetahuan .interaksi antara guru dengan siswa, maupun siswa dengan siswa. Guru dan siswa berbeda peran, guru sebagai fasilitator yang membimbing siswanya untuk dapat menemukan suatu konsep matematika, sedangkan siswa sebagai subjek dan objeknya.

\section{Karakteristik dan Langkah-langkah Pendekatan Matematika Realistik}

Pembelajaran matematika dengan pendekatan matematika realistik merupakan pembelajaran yang erat kaitannya dengan aktivitas manusia, dimana siswa harus diberikan kesempatan untuk belajar semua topik matematika yang didasarkan kepada lima karakteristik pembelajaran matematika. Traffers menjelaskan lima karakteristik pembelajaran matematika, yaitu: Phenomenological exploration or use context (menggunakan masalah kontekstual), masalah kontekstual dipandang sebagai titik awal pembelajaran sehingga konsep matematika yang diinginkan dapat muncul dalam kemampuan matematis 
siswa. ${ }^{18}$ Kemudian the use models or bridging by vertical instrumen (menggunakan model). Model berkaitan dengan model situasi matematika dikembangkan sendiri oleh siswa digunakan sebagai representasi dari suatu masalah untuk mempermudah penyelesaian masalah. The use of student's own productions and constructions of student's contribution (menggunakan kontribusi dan produksi siswa), kontribusi dalam pembelajaran realistik diharapkan lebih besar datang dari siswa sendiri melalui kegiatan konstruksi, antisipasi, maupun integrasi dalam pembelajaran sehingga siswa dapat menemukan konsep matematika.

Selanjutnya the interactive character of teaching process or interactivity (proses pembelajaran dengan pendekatan realistik dilaksanakan secara interaktif), interaksi antara siswa dengan siswa dan siswa dengan guru merupakan hal penting dalam pendekatan realistik. Adapun prinsip intertwining or various learning strand (pembelajaran membutuhkan adanya keterkaitan dengan unit atau topik lain yang nyata secara utuh) konsep yang dipelajari siswa dengan prinsip-prinsip belajar-mengajar matematika realistik harus merupakan jalinan dengan konsep atau materi lain baik dalam matematika itu sendiri maupun dengan yang lain.

Karakteristik di atas menjelaskan bagaimana seharusnya pembelajaran matematika harus realistik, dalam bahasa Belanda kata realiseren berarti membayangkan. Jadi, pembelajaran matematika realistik dapat diartikan sebagai pembelajaran matematika yang dapat dibayangkan oleh siswa. Karena itu, pembelajaran matematika harus dimulai dengan masalah yang diambil dari dunia nyata supaya siswa dapat membayangkannya. Masalah yang dipilih harus disesuaikan dengan konteks kehidupan siswa. Artinya, masalah yang dipilih harus dikenal baik oleh siswa.

Adapun langkah-langkah pembelajaran matematika dengan menggunakan pendekatan matematika realistik yaitu: Pertama, menggunakan masalah kontekstual. Kedua, menggunakan model atau jembatan dengan instrumen vertikal yaitu mengarahkan perhatian pada pengenalan model, skema, dan simbolisasi daripada mentransfer rumus atau matematika formal secara langsung. Ketiga menggunakan kontribusi siswa. Keempat, adanya interaktif antara guru dan siswa dalam proses pembelajaran. Negosiasi secara eksplisit, intervensi, kooperasi, dan evaluasi sesama murid dan guru adalah faktor penting dalam proses pembelajaran secara konstruktif dengan menggunakan strategi informal murid sebagai jantung untuk mencapai yang formal. Kelima, menggunakan berbagai teori belajar yang relevan, saling terkait, dan terintegrasi dengan topik pembelajaran lainnya. 


\section{Berpikir Kreatif}

\section{a. Pengertian Berpikir Kreatif}

Munandar mendefinisikan kreativitas sebagai kemampuan untuk membuat kombinasi baru, berdasarkan data, informasi, atau unsur-unsur yang ada. ${ }^{19}$ Kreativitas disebut juga berfikir kreatif atau divergen yaitu suatu kemampuan berdasarkan data atau informasi yang bersedia menemukan banyak kemungkinan jawaban terhadap suatu masalah, dimana penekanannya adalah pada kuantitas, ketepatgunaan, dan keragaman jawaban. Jadi secara operasional kreativitas dapat dirumuskan sebagai kemampuan yang mencerminkan kelancaran, keluwesan (fleksibilitas) dan rasionalitas dalam berfikir, serta kemampuan untuk mengelaborasi (mengembangkan, memperkaya, memperinci) suatu gagasan.

\section{b. Indikator Kemampuan Berpikir Kreatif}

Menurut Munandar Indikator kemampuan berpikir kreatif diantaranya Berpikir Lancar (fluency) yaitu: Mencetuskan banyak gagasan, penyelesaian masalah, atau jawaban, memberikan banyak cara atau saran untuk melakukan berbagai hal, dan Selalu memikirkan lebih dari satu jawaban. ${ }^{20}$

Berpikir Luwes (flexibility) yaitu: Menghasilkan gagasan, jawaban, atau pertanyaan yang bervariasi, dapat melihat suatu masalah dari sudut pandang yang berbeda, mencari banyak alternatif atau arah yang berbedabeda, dan mampu mengubah cara pendekatan atau pemikiran.

Berpikir Orisinil (originality) yaitu: Mampu melahirkan ungkapan yang baru dan unik. memikirkan cara-cara yang tak lazim untuk mengungkapkan diri, dan mampu membuat kombinasi yang tak lazim dari bagian-bagian atau unsur-unsur.

Berpikir Terperinci (elaboration) yaitu: Mampu memperkaya dan mengembangkan suatu gagasan atau produk, menambah atau merinci detail-detail dari suatu objek, gagasan, atau situasi sehingga menjadi lebih menarik.

${ }^{19}$ Utami Munandar, Mengembangkan Bakat Dan Kreativitas Anak Sekolah (Jakarta:

PT. Grasindo, 1992).

${ }^{20}$ Munandar. 
Berpikir Evaluatif (evaluation) yaitu: Menentukan patokan-patokan penilaian sendiri dan menentukan apakah suatu pernyataan benar, suatu rencana sehat atau suatu tindakan bijaksana. Mampu mengambil keputusan terhadap situasi yang terbuka, Tidak hanya mencetuskan gagasan-gagasan tetapi juga melaksanakannya.

\section{Koneksi Matematis}

\section{A. Pengertian Koneksi Matematis}

Menurut Suherman, dkk. "Matematika bukanlah pengetahuan menyendiri yang dapat sempurna karena dirinya sendiri, tetapi adanya matematika itu terutama untuk membantu manusia dalam memahami dan menguasai permasalahan sosial, ekonomi, dan alam. ${ }^{21}$

Secara umum, NCTM menyebutkan bahwa terdapat tiga tujuan koneksi matematis dalam pembelajaran matematika di sekolah, yaitu untuk memperluas wawasan pengetahuan siswa, memberikan pengertian kepada siswa agar memandang matematika sebagai suatu keseluruhan yang terpadu, bukan sebagai materi yang berdiri sendiri serta mengenal relevansi dan menunjukkan manfaat matematika baik di sekolah maupun di luar sekolah. ${ }^{22}$

Sesuai dengan salah satu tujuan umum diberikannya matematika pada jenjang pendidikan dasar dan menengah dalam Kurikulum 2006, yaitu mempersiapkan siswa agar dapat menggunakan matematika dan pola pikir matematika dalam kehidupan sehari-hari dan dalam mempelajari disiplin ilmu yang lainnya.

\section{B. Indikator Kemampuan Koneksi Matematis}

Menurut House dan Coxford koneksi matematis merupakan pengaitan antar topik matematika, matematika dengan mata pelajaran lain atau topik lain, serta pengaitan matematika dengan kehidupan), Dari beberapa indikator kemampuan koneksi matematis, indikator yang dimaksud adalah kemampuan siswa untuk menggunakan koneksi antara topik matematika dengan topik lain, menggunakan matematika dalam bidang studi lain dan menggunakan matematika dalam kehidupan seharihari. ${ }^{23}$ Pada dasarnya keterkaitan ilmu-ilmu lain dengan matematika

21 Suherman, Evaluasi Pembelajaran Matematika.

22 N. Puspitasari, “Pembelajaran Berbasis Masalah Dengan Strategi Kooperatif Jigsaw Untuk Meningkatkan Kemampuan Pemahaman Dan Koneksi Matematis Siswa Sekolah Menengah Pertama" (Universitas Pendidikan Indonesia, 2011).

23 Arsinah Rokhaeni, "Penerapan Model CORE Dalam Pembelajaran Matematika Untuk Meningkatkan Kemampuan Koneksi Matematis Siswa," Jurnal Pendidikan Matematika, 2011, 3. 
berasal dari kehidupan sehari-hari dan merupakan alat pemecahan masalah, disadari atau tidak kita sering menggunakan konsep matematika untuk penyelesaian masalah yang sederhana maupun masalah-masalah yang lebih kompleks. Kemampuan koneksi merupakan kemampuan yang harus dikuasai oleh siswa dalam belajar matematika agar pemahaman matematika siswa lebih mendalam dan tahan lama. Dengan memiliki kemampuan koneksi matematika maka siswa akan mampu melihat bahwa matematika itu suatu ilmu yang antar topiknya saling kait mengait serta bermanfaat dalam mempelajari pelajaran lain dan dalam kehidupan seharihari sehingga pembelajaran matematika itu nantinya terasa lebih indah dan bermakna.

\section{METODOLOGI}

\section{Metode Penelitian}

Metode yang digunakan dalam penelitian ini adalah metode kuasi eksperimen (eksperimen semu). Metode kuasi eksperimen adalah Penelitian yang mendekati percobaan sungguhan di mana tidak mungkin mengadakan kontrol, memanipulasikan semua variabel relevan, harus ada kompromi dalam menentukan validitas internal dan eksternal sesuai dengan batasan-batasan yang ada. ${ }^{24}$

Kriteria penting yang ada dalam penelitian eksperimen yaitu masalah penelitian harus masalah yang penting, dan diperkirakan dapat dipecahkan atau ditemukan jawaban dengan dukungan semua faktor, variabel, metode, material serta referensi dalam penelitian yang didefinisikan secara jelas, agar penelitian lebih efektif peneliti harus mampu memilih desain percobaan yang sesuai, sehingga memunculkan ketelitian dan ketepatan dalam kegiatan pengukuran. Dalam hal interpretasi dan uji statistik harus dinyatakan dalam signifikan dari parameter yang diestimasikan.

Pada penelitian ini terdapat dua kelompok kelas yang dibandingkan, yaitu kelas eksperimen dan kelas kontrol. Dari data populasi, terdapat enam Madrasah Ibtidaiyah Negeri untuk dijadikan sampel penelitian. Pengambilan sampel penelitian dilakukan berdasarkan teknik non probability sampling. Dengan teknik pengambilan sampel ini peneliti menentukan kelas eksperimen dan kelas kontrol, kemudian pada kedua kelas tersebut diberikan pre-test sebagai langkah untuk mengukur kesetaraan kemampuan awal subjek penelitian.

${ }^{24}$ I. Hatimah, R. Susiliana, and N Aedi, Penelitian Pendidikan (Bandung: UPI PRESS, 2006). 


\section{Desain Penelitian}

Desain yang digunakan dalam penelitian ini yaitu desain kelompok kontrol tidak ekuivalen (the non equivalent control group design). Desain kelompok kontrol tidak ekuivalen adalah "Desain yang kelompok eksperimen maupun kelompok kontrol tidak dipilih secara random" ${ }^{25}$

\section{Subjek Penelitian}

\section{a. Populasi}

Populasi pada penelitian ini adalah siswa-siswa Madrasah Ibtidaiyah Negeri (MIN) di Kota Bandung, dan siswa-siswa Madrasah Ibtidaiyah Negeri (MIN) di kota Sumedang.

\section{b. Sampel}

Teknik pengambilan sampel pada penelitian ini dilakukan dengan cara sampling purposive yang merupakan bagian dari teknik pengambilan sampel kelompok non probability sampling. ${ }^{26}$ Pada proses pengambilan sampel dilakukan dengan tidak memberikan kesempatan yang sama kepada unsur atau anggota dari populasi yang didapatkan, teknik pengambilan sampel ini ditentukan karena adanya berbagai pertimbangan peneliti.

Dalam menentukan kelas eksperimen dan kelas control yang diperhatikan adalah sekolah yang memiliki karakteristik atau sifat yang sama, serta sekolah berstatus negeri yang terakreditasi B dengan jumlah siswa, tenaga pendidik yang mempunyai latar belakang pendidikan yang setara, didukung dengan sarana dan prasarana pendidikan yang memenuhi kriteria. Selain itu peneliti mempertimbangkan berbagai aspek yang disesuaikan dengan judul penelitian "Pengaruh Pendekatan Matematika Realistik Terhadap Kemampuan Berpikir Kreatif dan Koneksi Matematis Siswa Kelas V Madrasah Ibtidaiyah Negeri“ berdasarkan hal tersebut maka peneliti memilih salah satu Sekolah Madrasah Ibtidaiyah Negeri yang ada di kota Bandung sebagai kelas eksperimen, dan Madrasah Ibtidaiyah Negeri yang dijadikan kelas control.

\section{Instrumen Penelitian}

Instrumen yang digunakan untuk memperoleh data dalam penelitian ini berupa tes dan non tes. Bentuk soal tes dalam penelitian ini berbentuk uraian. Keunggulan uraian dapat menimbulkan sifat kreatif pada diri siswa, kemampuan siswa akan lebih terlihat karena siswa yang mempunyai kesungguhan yang tinggi yang dapat menyelesaikan

${ }^{25}$ Sugiyono, Metode Penelitian Pendidikan (Bandung: CV Alfabeta, 2007).

26 Sugiyono, Statistika Untuk Penelitian (Bandung: CV Alfabeta, 2004). 
jawabannya dengan benar. ${ }^{27}$ Soal uraian dapat menghindari unsur tebaktebakan saat siswa membrikan jawaban, serta peneliti dapat memberikan penilaian dengan melihat berbagai cara penyelesaian dalam menjawab soal uraian yang diberikan. Instrumen tes dilakukan untuk mengetahui sejauh mana pengaruh pendekatan matematika realistik terhadap berpikir kreatif dan koneksi matematis siswa. Sedangkan instrumen non tes yang digunakan yaitu angket dan observasi. Angket digunakan untuk melihat respon siswa terhadap pembelajaran matematika dengan menggunakan pendekatan matematika realistic. Sedangkan observasi digunakan untuk mengamati dan mengukur kemandirian belajar siswa selama proses pembelajaran berlangsung serta merekam berbagai fenomena yang terjadi.

\section{Prosedur Penelitian}

a. Studi Kepustakaan

b. Membuat 2 rancangan pembelajaran untuk kelas eksperimen dan kelas kontrol.

c. Penyususnan soal, ujicoba, revisi, dan pengesahan instrumen.

d. Penentuan subjek penelitian.

e. Pelaksanaan pre-test

f. Pelaksanaan pembelajaran dan observasi

g. Pelaksanaan post-test

h. Pengumpulan data

i. Analisis data

j. Kesimpulan

\section{PEMBAHASAN}

\section{Pre-test dan post-test Kemampuan Berpikir Kreatif}

Berdasarkan hasil pre-test kemampuan berpikir kreatif matematis dengan jumlah sampel kedua kelas sama, dengan jumlah siswa masingmasing sebanyak 30 siswa. Pada rata-rata skor pre-test kemampuan berpikir kreatif matematis kelas eksperimen memiliki nilai rata-rata 8,20 dan lebih tinggi dari rata-rata kelas kontrol, yang hanya memiliki nilai rata-rata 6,70. Selisih rata-rata antara kedua kelas adalah 1,5 yang apabila dikonversikan dalam bentuk persentase pencapaian kelas eksperimen adalah $41 \%$ atau 7,5\% lebih tinggi daripada pencapaian rata-rata skor pre-test kemampuan berpikir kreatif matematis kelas kontrol yang hanya memperoleh 33,5\%. Perbedaan pencapaian antara kelas eksperimen dengan kelas kontrol masih tergolong rendah, sehingga kedua kelas memiliki kemampuan berpikir kreatif matematis awal yang relatif sama. Adapun hasil uji statistik

${ }_{27}$ Maulana, Memahami Hakikat, Variabel, Dan Intrumen Penelitian Pendidikan Dengan Benar (Bandung: Learn2live 'n Live2learn, 2009). 
menunjukkan, data berdistribusi normal dan bervariansi homogen, uji parametrik uji $\mathrm{t}$ dengan skor P-value (Sig.2 tailed) $=0,122$ pada taraf signifikansi $\alpha=0,05$ kondisi demikian $\mathrm{H}_{0}$ diterima artinya, tidak terdapat perbedaan yang signifikan skor pre-test kemampuan berpikir kreatif matematis siswa kelas eksperimen dan kelas kontrol.

Pada rata-rata skor post-test kemampuan berpikir kreatif matematis kelas eksperimen memiliki nilai rata-rata 14,93 dan lebih tinggi dari ratarata kelas kontrol, yang hanya memiliki nilai rata-rata 11,60 . Selisih ratarata antara kedua kelas adalah 3,33 yang apabila dikonversikan dalam bentuk persentase pencapaian kelas eksperimen adalah 74,65\% atau 16,65\% lebih tinggi daripada pencapaian rata-rata skor pre-test kemampuan berpikir kreatif matematis kelas kontrol yang hanya memperoleh 58\%. Perbedaan rata-rata kelas eksperimen lebih baik dari rata-rata kelas kontrol, sehingga kedua kelas memiliki kemampuan berpikir kreatif matematis akhir berbeda. Adapun hasil uji statistik menunjukkan, data berdistribusi normal dan bervariansi homogen, uji $\mathrm{t}$ dengan skor P-value (Sig.2 tailed) $=$ 0,000 pada taraf signifikansi $a=0,05$ kondisi demikian $\mathrm{H}_{0}$ ditolak artinya, terdapat perbedaan yang signifikan skor post-test kemampuan berpikir kreatif matematis siswa kelas eksperimen dan kelas kontrol. Berdasarkan hasil uji t dapat disimpulkan kemampuan berpikir kreatif matematis siswa yang memperoleh pembelajaran matematika dengan menggunakan pendekatan matematika realistik (kelas eksperimen) lebih baik dari kemampuan berpikir kreatif matematis siswa yang memperoleh pembelajaran matematika dengan menggunakan pembelajaran secara secara konvensional (kelas kontrol).

\section{a. Analisis Pencapaian Kemampuan Berpikir Kreatif}

Berdasarkan rata-rata skor pre-test kemampuan berpikir kreatif matematis kelas eksperimen memiliki nilai rata-rata 8,20 dan lebih tinggi dari rata-rata kelas kontrol, yang hanya memiliki nilai rata-rata 6,70. Selisih rata-rata antara kedua kelas adalah 1,5 yang apabila dikonversikan dalam bentuk persentase pencapaian kelas eksperimen adalah $41 \%$ atau 7,5\% lebih tinggi daripada pencapaian rata-rata skor pre-test kemampuan berpikir kreatif matematis kelas kontrol yang hanya memperoleh 33,5\%. Perbedaan pencapaian antara kelas eksperimen dengan kelas kontrol masih tergolong rendah, sehingga kedua kelas memiliki kemampuan berpikir kreatif matematis awal yang relatif sama. Akan tetapi pada rata-rata skor post-test kemampuan berpikir kreatif matematis kelas eksperimen memiliki nilai rata-rata 14,93 dan lebih tinggi dari rata-rata kelas kontrol, yang hanya memiliki nilai rata-rata 11,60. Selisih rata-rata antara kedua kelas adalah 3,33 yang apabila dikonversikan dalam bentuk persetase pencapaian kelas eksperimen adalah $74,65 \%$ lebih tinggi daripada pencapaian rata-rata skor pre-test kemampuan berpikir kreatif matematis kelas kontrol yang hanya 
memperoleh 58\%. Perbedaan rata-rata kelas eksperimen lebih baik dari rata rata kelas kontrol. Berdasarkan hasil analisis pre-test dan post-test skor terdapat perbedaan antara pencapaian rata-rata skor pre-test kemampuan berpikir kreatif matematis kelas eksperimen dan kelas kontrol sebesar $7,5 \%$, persentase rata-rata pre-test kemampuan berpikir kreatif matematis kelas eksperimen lebih tinggi dari persentase rata-rata pre-test kemampuan berpikir kreatif matematis kelas kontrol. Adapun hasil analisis post-test terdapat perbedaan antara pencapaian rata-rata skor post-test kemampuan berpikir kreatif matematis kelas eksperimen dan kelas kontrol sebesar $16,65 \%$ persentase rata-rata post-test kemampuan berpikir kreatif matematis kelas eksperimen lebih tinggi dari persentase rata-rata post-test kemampuan berpikir kreatif matematis kelas kontrol, dengan demikian dapat disimpulkan kemampuan berpikir kreatif siswa yang memperoleh pembelajaran matematika dengan menggunakan pendekatan matematika realistik lebih baik dari siswa yang memperoleh pembelajaran matematika dengan pembelajaran secara konvensional.

\section{b. Analisis Peningkatan Kemampuan Berpikir Kreatif}

Nilai rata-rata data N-Gain kemampuan berpikir kreatif matematis siswa kelas eksperimen dan kelas kontrol dengan perbedaan $26 \%$. Skor pada kolom mean nilai N-Gain untuk kelas eksperimen $=0,60$ atau 60\% lebih besar daripada rata-rata skor N-Gain kelas kontrol $=0,34$ atau 34\%. Untuk membuktikan peningkatan kemampuan berpikir kreatif matematis siswa yang memperoleh pembelajaran matematika dengan menggunakan pendekatan matematika realistik lebih baik dibandingkan dengan siswa yang memperoleh pembelajaran matematika dengan menggunakan pendekatan konvensional dilakukan uji statistik, nilai rata-rata N-Gain berdistribusi normal dengan variansi homogen, uji yang dilakukan selanjutnya uji parametrik, yaitu: Uji $\mathrm{t}$ dengan skor P-value (Sig.2 tailed) = 0,000 pada taraf signifikansi $a=0,05$ kondisi demikian $\mathrm{H}_{0}$ ditolak artinya, terdapat perbedaan yang signifikan terhadap skor N-Gain kemampuan berpikir kreatif matematis siswa kelas eksperimen dan kelas kontrol. Berdasarkan hasil uji t skor N-Gain kemampuan berpikir kreatif matematis siswa pada kelas eksperimen dan kelas kontrol dapat disimpulkan bahwa peningkatan kemampuan berpikir kreatif siswa yang memperoleh pembelajaran matematika dengan menggunakan pendekatan matematika realistik lebih baik dari siswa yang memperoleh pembelajaran matematika dengan pembelajaran secara konvensional.

\section{Analisis Pre-test dan Post-test Kemampuan Koneksi Matematis}

Berdasarkan data hasil pre-test kemampuan koneksi matematis dengan jumlah sampel sama, masing-masing sebanyak 30 siswa. Pada rata- 
rata skor pre-test kemampuan koneksi matematis kelas eksperimen memiliki nilai rata-rata 2,40 dan lebih tinggi dari rata-rata kelas kontrol, yang hanya memiliki nilai rata-rata 1,93, selisih rata-rata antara kedua kelas adalah 0,47. Apabila dikonversikan dalam bentuk persentase pencapaian kelas eksperimen adalah $26,67 \%$ atau 5,22\% lebih tinggi dari pencapaian rata-rata skor pre-test kemampuan koneksi matematis kelas kontrol yang hanya memperoleh 21,44\%. Perbedaan pencapaian antara kelas eksperimen dengan kelas kontrol masih tergolong rendah, sehingga kedua kelas memiliki kemampuan berpikir kreatif matematis awal yang relatif sama. Untuk membuktikan perbedaan kemampuan koneksi matematis kedua kelas dilakukan uji statistik lebih lanjut dengan hasil data berdistribusi tidak normal dengan hasil uji Mann-Whitney perbedaan ratarata pre-test kemampuan koneksi matematis siswa kelas eksperimen dan kelas kontrol dengan taraf signifikansi $a=0,05$ didapatkan nilai $P$-value (Sig.2 tailed) $=0,241>0,05=$ a Kondisi demikian $\mathrm{H}_{0}$ diterima artinya, tidak terdapat perbedaan yang signifikan kemampuan awal koneksi matematis siswa pada kelas eksperimen dan kelas kontrol.

Pada rata-rata skor post-test kemampuan koneksi matematis kelas eksperimen memiliki nilai rata-rata 5,90 dan lebih tinggi dari rata-rata kelas kontrol, yang hanya memiliki nilai rata-rata 4,90. Selisih rata-rata antara kedua kelas adalah 1.00. Apabila dikonversikan dalam bentuk persetase pencapaian kelas eksperimen adalah $65,56 \%$ atau $11,11 \%$ lebih tinggi dari pencapaian rata-rata skor pre-test kemampuan koneksi matematis kelas kontrol yang hanya memperoleh $54,44 \%$. Perbedaan rata-rata kelas eksperimen lebih baik dari rata-rata kelas kontrol. Untuk membuktikan perbedaan rata-rata post-test kemampuan koneksi dilakukan uji statistik, berdasarkan uji normalitas data berditribusi tidak normal dilanjutkan dengan uji Mann-Whitney perbedaan rata-rata post-test kemampuan koneksi matematis siswa kelas eksperimen dan kelas kontrol dengan taraf signifikansi $\mathrm{a}=0,05$ didapatkan nilai P-value (Sig. 2 tailed) $=0,071>0,05=\mathrm{a}$ Kondisi demikian $\mathrm{H}_{0}$ diterima artinya, tidak terdapat perbedaan kemampuan koneksi matematis siswa pada kelas eksperimen dan kelas kontrol.

\section{a. Analsis Pencapaian Kemampuan Koneksi Matematis}

Berdasarkan rata-rata skor pre-test kemampuan koneksi matematis kelas eksperimen memiliki nilai rata-rata 2,40 dan lebih tinggi dari rata-rata kelas kontrol, yang hanya memiliki nilai rata-rata 1,93, selisih rata-rata antara kedua kelas adalah 0,47. Apabila dikonversikan dalam bentuk persentase pencapaian kelas eksperimen adalah 26,67\% lebih tinggi dari pencapaian rata-rata skor pre-test kemampuan koneksi matematis kelas kontrol yang hanya memperoleh $21,44 \%$. Adapun rata-rata skor post-test kemampuan koneksi matematis kelas eksperimen memiliki nilai rata-rata 
5,90 dan lebih tinggi dari rata-rata kelas kontrol, yang hanya memiliki nilai rata-rata 4,90. Selisih rata-rata antara kedua kelas adalah 1.00. Apabila dikonversikan dalam bentuk persentase pencapaian kelas eksperimen adalah 65,56\% lebih tinggi dari pencapaian rata-rata skor pre-test kemampuan koneksi matematis kelas kontrol yang hanya memperoleh $54,44 \%$.

Berdasarkan hasil analisis pencapaian skor pre-test dan post-test kemampuan koneksi matematis siswa kelas eksperimen maupun kelas kontrol terdapat perbedaan antara pencapaian rata-rata skor pre-test kemampuan koneksi matematis kelas eksperimen dan kelas kontrol sebesar 5,22\%, persentase rata-rata pre-test kemampuan koneksi matematis kelas eksperimen lebih tinggi dari persentase rata-rata pre-test kemampuan koneksi matematis kelas kontrol. Adapun hasil analisis post-test terdapat perbedaan antara pencapaian rata-rata skor post-test kemampuan koneksi matematis kelas eksperimen dan kelas kontrol sebesar $11,11 \%$ persentase rata-rata post-test kemampuan koneksi matematis kelas eksperimen lebih tinggi daripada persentase rata-rata post-test kemampuan koneksi matematis kelas kontrol, dengan demikian dapat disimpulkan kemampuan koneksi siswa yang memperoleh pembelajaran matematika dengan menggunakan pendekatan matematika realistik lebih baik dari siswa yang memperoleh pembelajaran matematika dengan pembelajaran konvensional.

\section{b. Analisis Peningkatan Kemampuan Koneksi Matematis}

Nilai rata-rata data N-Gain kemampuan koneksi matematis siswa kelas eksperimen dan kelas kontrol berbeda, dengan perbedaan $12 \%$. Skor pada kolom mean nilai N-Gain untuk kelas eksperimen $=0,55$ atau 55\% lebih besar daripada rata-rata skor N-Gain kelas kontrol $=0,43$ atau $43 \%$. Untuk membuktikan peningkatan kemampuan koneksi matematis siswa yang memperoleh pembelajaran matematika dengan menggunakan pendekatan matematika realistik lebih baik dibandingkan dengan siswa yang memperoleh pembelajaran matematika dengan menggunakan pendekatan konvensional. Berdasarkan uji normalitas data berdistribusi normal akan tetapi tidak bervariansi homogen, untuk uji selanjutnya dilakukan uji-t' (Independent Sample t-test) dengan taraf signifikansi $\alpha=0,05$ didapatkan nilai P-value (Sig.2tailed) kolom equal variances not assumed $=0,047<\mathrm{a}=0,05$. Kondisi demikian menunjukkan bahwa $H_{0}$ ditolak. Artinya terdapat perbedaan peningkatan yang signifikan kemampuan koneksi matematis siswa yang memperoleh pembelajaran dengan menggunakan pendekatan matematika realistik dan siswa memperoleh pembelajaran dengan pembelajaran secara konvensional. Perbedaan juga tampak rata-rata skor $\mathrm{N}$-Gain kelompok eksperimen berbeda dengan rata-rata N-Gain kelompok kontrol, dan ternyata rata-rata skor N-Gain kelompok eksperimen lebih 
tinggi. Artinya, peningkatan Kemampuan koneksi matematis siswa yang memperoleh pembelajaran matematika dengan menggunakan pendekatan matematika realistik lebih baik dari siswa yang belajar dengan pembelajaran secara konvensional.

\section{E. KESIMPULAN}

Beberapa hal yang dapat disimpulkan dari penelitian yang telah dilakukan adalah sebagai berikut.

1. Pencapaian kemampuan berpikir kreatif dan koneksi matematis siswa yang memperoleh pembelajaran matematika dengan menggunakan pendekatan matematika realistik secara signifikan lebih baik dari siswa yang memperoleh pembelajaran matematika dengan pembelajaran secara konvensional.

2. Peningkatan kemampuan berpikir kreatif dan koneksi matematis siswa yang memperoleh pembelajaran matematika dengan menggunakan pendekatan matematika realistik secara signifikan lebih baik dari siswa yang memperoleh pembelajaran matematika dengan pembelajaran secara konvensional.

3. Terdapat korelasi antara kemampuan berpikir kreatif dengan kemampuan koneksi matematis siswa yang memperoleh pembelajaran matematika dengan menggunakan pendekatan matematika realistik, korelasi keduanya diinterpretasikan termasuk dalam tingkatan tinggi.

4. Respon siswa terhadap pembelajaran matematika dengan menggunakan pendekatan matematika realistik diinterpretasikan baik, hal ini berdasarkan angket bahwa $86,08 \%$ atau 26 siswa dari 30 siswa yang berada di kelas eksperimen merespon positif pembelajaran matematika dengan menggunakan pendekatan matematika realistik dalam materi pecahan.

\section{F. DAFTAR PUSTAKA}

Arsinah Rokhaeni. "Penerapan Model CORE Dalam Pembelajaran Matematika Untuk Meningkatkan Kemampuan Koneksi Matematis Siswa." Jurnal Pendidikan Matematika, 2011, 3.

Asrori, M. Psikologi Pembelajaran. Bandung: CV Wacana Prima Press, 2009.

Hatimah, I., R. Susiliana, and N Aedi. Penelitian Pendidikan. Bandung: UPI PRESS, 2006.

Irzani. Pembelajaran Matematika Panduan Praktis Untuk Pengajar SD \& MI. Yogyakarta: Mandiri Graffindo Press, 2010. 
Jarret, D. “Open-Ended Problem Solving Weaving a Web of Idea Northwest Teacher." Potland: Northwest Regional Educational Laboratory 1, no. 1 (2000).

Kebudayaan, Kementrian Pendidikan dan. Permendikbud no.64 tentang standar isi pendidikan dasar dan menengah (2013).

Khususwanto. "Pembelajaran Matematika Dengan Pendekatan Resourcebased Learning Untuk Meningkatkan Kemampuan Berpikir Kreatif Matematis SMP." Universitas Pendidikan Indonesia, 2013.

Lambertus. "Peningkatan Kemampuan Berpikir Kreatif Dan Kemampuan Pemecahan Masalah Matematik Siswa SD Melalui Pendekatan Matematika Realistik." Universitas Pendidikan Indonesia, 2010.

Maulana. Memahami Hakikat, Variabel, Dan Intrumen Penelitian Pendidikan Dengan Benar. Bandung: Learn2live 'n Live2learn, 2009.

Munandar, Utami. Mengembangkan Bakat Dan Kreativitas Anak Sekolah. Jakarta: PT. Grasindo, 1992.

Pitajeng. Pembelajaran Matematika Yang Menyenangkan. Jakarta: Depdiknas, 2006.

Puspitasari, N. "Pembelajaran Berbasis Masalah Dengan Strategi Kooperatif Jigsaw Untuk Meningkatkan Kemampuan Pemahaman Dan Koneksi Matematis Siswa Sekolah Menengah Pertama." Universitas Pendidikan Indonesia, 2011.

Ruseffendi, E. T. Pendidikan Matematika III. Jakarta: Depdikbud Proyek Pembinaan Tenaga Kependidikan Perguruan Tinggi, 1998.

Sugiyono. Metode Penelitian Pendidikan. Bandung: CV Alfabeta, 2007.

- - - Statistika Untuk Penelitian. Bandung: CV Alfabeta, 2004.

Suherman, E. Evaluasi Pembelajaran Matematika. Bandung: FPMIPA UPI, 2003.

Swangsih, E., and Tiurlina. Model Pembelajaran Matematika. Bandung: UPI PRESS, 2009.

Tarigan, D. Pembelajaran Matematika Realistik. Jakarta: Depdiknas, 2006.

Wahyudin. "Pembelajaran Dan Model Model Pembelajaran: Pelengkap Untuk Meningkatkan Pedagogis Para Guru Dan Calon Guru Profesional." Bandung, 2008.

Wijaya, A. Pendidikan Matematika Realistik. Yogyakarta: Graha Ilmu, 2011. 